\title{
From simple to supercomplex: mitochondrial genomes of
}

\section{euglenozoan protists [version 1; peer review: 2 approved]}

\author{
Drahomíra Faktorová1,2* ${ }^{*}$ Eva Dobáková1,3* , Priscila Peña-Diaz ${ }^{1 *}$, Julius Lukeš1,2,4
}

\author{
${ }^{1}$ Institute of Parasitology, Biology Centre, Czech Academy of Sciences, Prague, Czech Republic \\ ${ }^{2}$ Faculty of Sciences, University of South Bohemia, Ceske Budejovice, České Budějovice (Budweis), Czech Republic \\ ${ }^{3}$ Departments of Biochemistry and Genetics, Faculty of Natural Sciences, Comenius Universtity, Bratislava, Slovakia \\ ${ }^{4}$ Canadian Institute for Adavanced Research, Toronto, Ontario, Canada \\ * Equal contributors
}

V1 First published: 23 Mar 2016, 5(F1000 Faculty Rev):392

https://doi.org/10.12688/f1000research.8040.1

Latest published: 29 Nov 2016, 5(F1000 Faculty Rev):392

https://doi.org/10.12688/f1000research.8040.2

\begin{abstract}
Mitochondria are double membrane organelles of endosymbiotic origin, best known for constituting the centre of energetics of a eukaryotic cell. They contain their own mitochondrial genome, which as a consequence of gradual reduction during evolution typically contains less than two dozens of genes. In this review, we highlight the extremely diverse architecture of mitochondrial genomes and mechanisms of gene expression between the three sister groups constituting the phylum Euglenozoa - Euglenida, Diplonemea and Kinetoplastea. The earliest diverging euglenids possess a simplified mitochondrial genome and a conventional gene expression, whereas both are highly complex in the two other groups. The expression of their mitochondrial-encoded proteins requires extensive posttranscriptional modifications guided by complex protein machineries and multiple small RNA molecules. Moreover, the least studied diplonemids, which have been recently discovered as a highly abundant component of the world ocean plankton, possess one of the most complicated mitochondrial genome organisations known to date.
\end{abstract}

\section{Keywords}

mitochondria, euglenozoa, mitochondrial genome

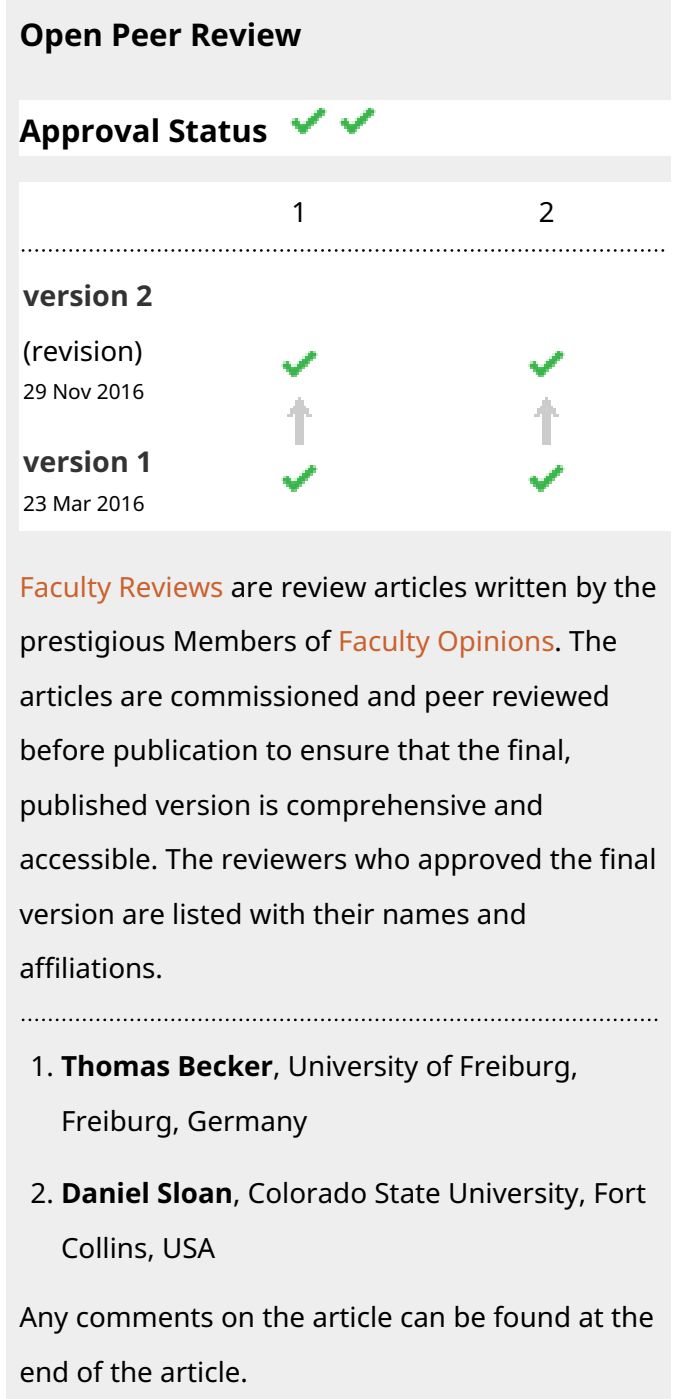


Corresponding author: Julius Lukeš (jula@paru.cas.cz)

Competing interests: The authors declare that they have no competing interests.

Grant information: This work was funded by Gordon and Betty Moore Foundation grant GBMF4983 and Czech Grant Agency 15-21974S to Julius Lukeš.

The funders had no role in study design, data collection and analysis, decision to publish, or preparation of the manuscript.

Copyright: @ 2016 Faktorová D et al. This is an open access article distributed under the terms of the Creative Commons Attribution License, which permits unrestricted use, distribution, and reproduction in any medium, provided the original work is properly cited.

How to cite this article: Faktorová D, Dobáková E, Peña-Diaz $P$ and Lukeš J. From simple to supercomplex: mitochondrial genomes of euglenozoan protists [version 1; peer review: 2 approved] F1000Research 2016, 5(F1000 Faculty Rev):392

https://doi.org/10.12688/f1000research.8040.1

First published: 23 Mar 2016, 5(F1000 Faculty Rev):392 https://doi.org/10.12688/f1000research.8040.1 


\section{Introduction}

The phylum Euglenozoa, which is part of the supergroup Excavata that significantly diverged from other eukaryotic lineages, is composed of three geographically ubiquitous groups of flagellated protists: Euglenida, Diplonemea, and Kinetoplastea (the fourth group, Symbiontida, has no molecular data available and thus will not be discussed here) $)^{1}$. The well-known representatives of these groups are Euglena for euglenids and Trypanosoma for kinetoplastids, whereas diplonemids are very poorly known. Although the Euglenozoa is a stable and highly supported group, mutual phylogenetic relationships among these three groups are not yet fully resolved, and euglenids likely constitute the earliest offshoot (Figure 1) $)^{1-3}$.

Euglenozoans have several common morphological features, such as subpellicular microtubules and a single flagellum or two heterodynamic flagella, protruding from an anterior pocket. Their lifestyles vary greatly, ranging from the free-living photosynthetic euglenids to intra- and extracellular parasites of plants, insects, and mammals, including humans. We do not yet know the predominant lifestyle of diplonemids, a group that recently came into the spotlight thanks to the Tara Oceans expedition, which revealed their global presence and extreme abundance in the world ocean. Indeed, diplonemids may comprise the sixth most abundant and third most species-rich group of marine eukaryotes ${ }^{4,5}$. The euglenids and diplonemids display different modes of nutrition; the former are characterized by photoautotrophy, whereas the latter are likely phagotrophs, osmotrophs, or parasites or a combination of these. The predominantly parasitic kinetoplastids make use of the carbon sources provided by their hosts ${ }^{6,7}$.

A hallmark feature of euglenozoans is a single large mitochondrion, frequently reticulated and displaying cristae with a discoid structure $^{1,8}$. As all mitochondria of aerobic protists, it contains mitochondrial DNA (mtDNA $)^{7}$. Although as vestigial as mtDNAs of other eukaryotes, this organellar genome evolved in euglenozoan protists into a stunning variety of structures and organizations, as described in more detail below. With the advent of affordable high-throughput sequencing, thousands of $\mathrm{mt}$ genomes are being assembled and annotated. However, their selection remains strongly skewed toward the metazoans, which mostly harbor standard, highly reduced, and streamlined mt genomes? Yet the majority of extant eukaryotic diversity is constituted by protists $^{10}$, of which only a very small fraction has their mtDNA

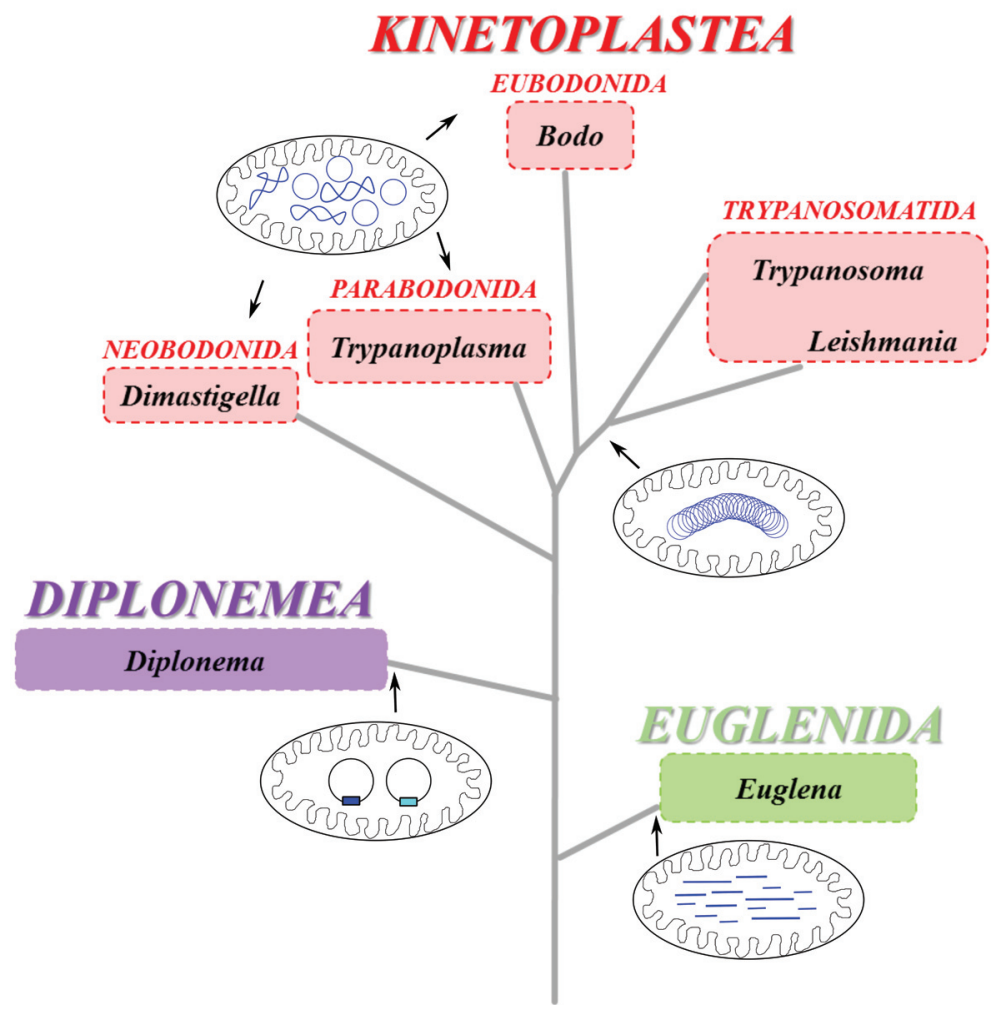

Figure 1. Schematic phylogenetic tree of representative genera of Euglenozoa depicting the organization of their mitochondrial genomes. The scheme is based on Adl et al. ${ }^{1}$ (2012). Different organization of their mitochondrial genomes (in blue) is shown for the three major lineages: Kinetoplastea (in red), Diplonemea (in purple), and Euglenida (in green). Whereas Euglenida possess an array of linear mitochondrial DNA molecules of variable length, Diplonemea and Kinetoplastida contain in their organelle circular DNA molecules in different arrangements. In Diplonemea, circular molecules of two sizes are non-catenated and supercoiled. The kinetoplast DNA of Eubodonida, Parabodonida, and Neobodonida is composed of numerous free, non-catenated relaxed or supercoiled DNA circles, whereas in Trypanosomatida it is constituted of thousands of relaxed circles, mutually interlocked into a single giant network composed of interlocked maxicircles and minicircles that together with proteins are packaged into a single compact disk. 
characterized. Still, the available mt genomes of protists show a range of bizarre gene arrangements, modes of organization, and complex post-transcriptional maturations ${ }^{11,12}$. Hence, it does not come as a surprise that some authors consider further sequencing of mt genomes of metazoans as superfluous and non-informative but that at the same time they call for focusing efforts onto the organellar genomes of hitherto-neglected protist groups ${ }^{12}$.

\section{Mitochondrial genome architecture and gene content}

Standard mt genomes are usually represented by a circular or linear DNA molecule encoding an average of fewer than two dozen genes ranging from 2 to 66 proteins in Chromera velia and Andalucia godoyi ${ }^{13,14}$. Although euglenozoans harbor a low number of genes in their $\mathrm{mt}$ genomes, they developed an extremely variable genome architecture. In euglenids and diplonemids, mtDNA seems to be evenly distributed throughout the lumen of the organelle ${ }^{8,15}$, and the picture is more complex in kinetoplastids (Figure 2). Whereas in the obligatory parasitic trypanosomatids it is invariably compacted into a single disk-shaped structure of concatenated DNA termed the kinetoplast DNA (kDNA), the free-living or commensalic bodonids have their kDNA distributed either evenly or in foci in the mt lumen ${ }^{16}$.

The best-studied kDNA is that of the human pathogen and model organism Trypanosoma brucei (for current reviews, see 17-19). It is composed of thousands of DNA circles mutually interlocked into a single network (Figure 2) that is densely packed into a disk-shaped structure located close to the basal body of the flagellum. The kDNA network of T. brucei and related flagellates is formed of dozens of maxicircles, each about $20 \mathrm{~kb}$ long, and of approximately 5,000 uniformly sized $(\sim 1.0 \mathrm{~kb})$ minicircles ${ }^{20}$. The maxicircle is composed of a single conserved region, which contains all protein-coding and rRNA genes, and a shorter variable region of species-specific size and sequence, which probably plays a role in replication ${ }^{21-23}$. The conserved region carries 18 protein-coding genes, mostly subunits of respiratory complexes (complex I: nad1, nad2, nad3, nad4, nad5, nad7, nad8, and nad9; complex III: cob; complex IV: cox1, cox2, and cox3; complex V: atp6), one ribosomal protein (rpll2), small and large mito-rRNA genes ( $12 S$ and $9 S)$, and four open reading frames of unknown function (MURF2, MURF5,

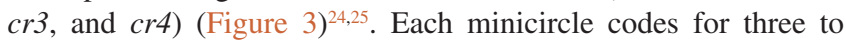
five small guide RNA (gRNA) genes, accounting for a total coding capacity of the kDNA of approximately 1,200 different gRNAs within approximately 250 distinct minicircle classes ${ }^{26}$. The gRNAs provide information for post-transcriptional RNA editing in the form of multiple insertions and deletions of uridine residues into the maxicircle-derived mRNAs (for recent reviews, see 19,27,28). The kDNA does not encode tRNA genes, and hence all tRNA molecules must be imported from the cytosol ${ }^{29,30}$.

The mtDNA of the diplonemid Diplonema papillatum is composed of numerous free DNA circles (Figure 1) with a total coding capacity of about $600 \mathrm{~kb}^{31}$. The circles are distinguished by size and
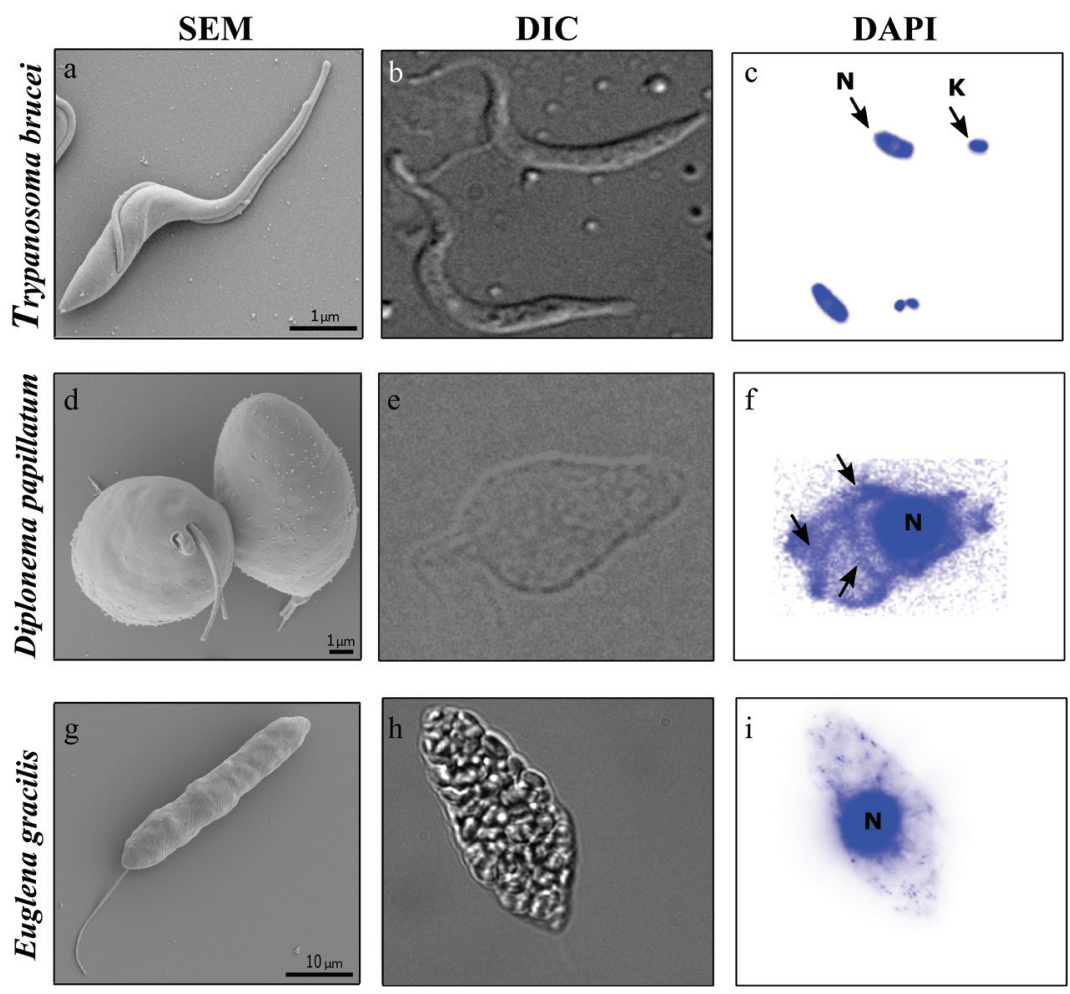

Figure 2. Morphology of representatives of Kinetoplastea (Trypanosoma brucei), Diplonemea (Diplonema papillatum), and Euglenida (Euglena gracilis). Scanning electron microscopy (SEM) (a, d, g) and differential interference contrast (DIC) (b, e, h) reveal cell morphology, whereas 4',6-diamidino-2-phenylindole (DAPI) staining provides information about the amount and distribution of mitochondrial DNA $(\mathbf{c}, \mathbf{f}, \mathbf{i})$. (c) Trypanosoma with distinct nucleus $(\mathrm{N})$ and kinetoplast $(\mathrm{K})$. (f) In Diplonema, arrows point to large amounts of mitochondrial DNA meandering through the cell. Scale bars $=1 \mu \mathrm{m}(\mathbf{a}, \mathbf{d})$ and $10 \mu \mathrm{m}(\mathbf{g})$. 


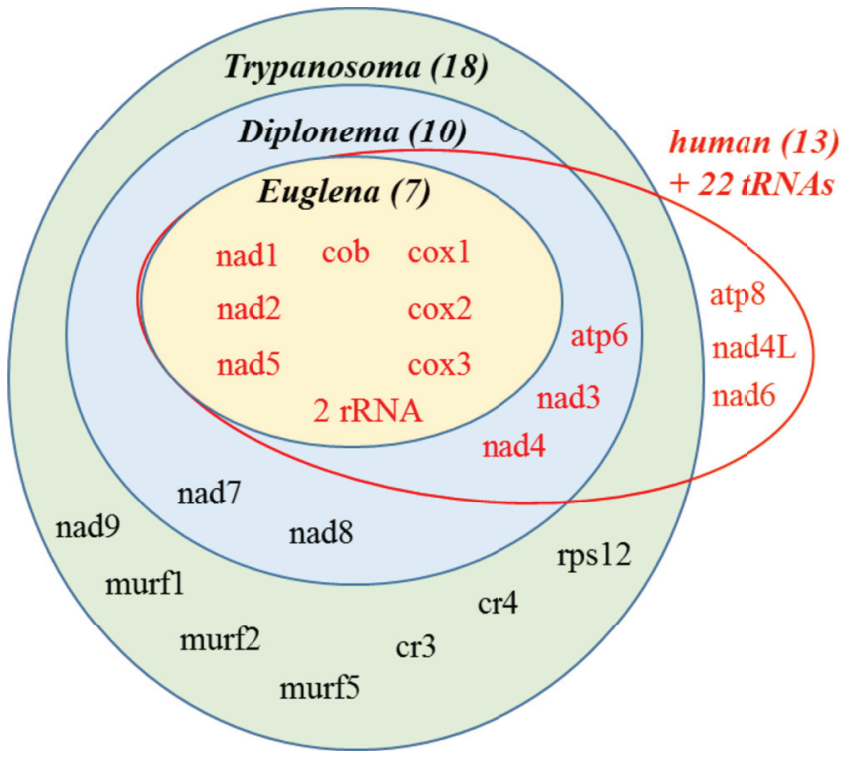

Figure 3. Schematic representation of the coding capacity of mitochondrial genomes of representative euglenozoans and human. The number of protein-coding genes is shown in parentheses next to selected euglenozoan flagellates. The number of protein-coding genes found in Euglena (orange oval), Diplonema (blue oval), and Trypanosoma is depicted (green oval). In comparison, human mitochondrial genome encodes 13 proteins (in red). All euglenozoans most likely contain small subunit and large subunit mito-rRNAs that in Diplonema and Euglena are likely to be highly divergent.

sequence of their non-coding regions into a 6.0 and $7.0 \mathrm{~kb}-$ long $\mathrm{A}$ and $\mathrm{B}$ class, respectively ${ }^{32}$. Although the function of the noncoding region representing up to $95 \%$ of the circle is unknown, each circle also carries a single cassette composed of a gene module, flanked upstream and downstream by an invariable 50-bp region, which represents a fragment of a protein-coding gene ${ }^{31-34}$. Although the genes are uniquely fragmented, the gene content of Diplonema is rather standard and similar to that of kDNA of the kinetoplastid flagellates, as it specifies subunits of respiratory complexes (complex I: nad1, 4, 5, 7, and 8; complex III: cob; complex IV: coxl-3; complex V: atp6) and large subunit (LSU) mito-rRNA ${ }^{31}$. The absence of the small subunit (SSU) mito-rRNA is explained by its being diverged beyond recognition, as the LSU gene is fragmented and extremely diverged, which made its identification challenging ${ }^{34}$. So far, all identified mt-encoded genes of Diplonema are fragmented, hence must be uniquely trans-spliced into fully translatable mRNAs by a hitherto-unknown mechanism.

The mtDNA of Euglena, the model euglenid, is surprisingly simple when compared with the highly complex genomes of its sister groups. Indeed, the genome is streamlined in terms of both its architecture and gene content. The mtDNA of Euglena is represented by a pool of recombination-prone short linear molecules containing repeats, pieces of non-functional gene fragments, and full-length gene copies, which ensure the production of functional proteins. The set of only three protein-coding genes $(\operatorname{cox} 1-3)^{35,36}$ was recently complemented by four intact genes encoding additional subunits of the respiratory chain (nadl, 4, and 5 and $\mathrm{cob})^{37}$. The genes encoding subunits of complex $\mathrm{V}$ and ribosomal proteins are missing. The SSU and LSU of mito-rRNA are likely split into two fragments each (SSU-R, SSU-L and LSU-R, LSU-L). However, only the SSU-R fragment has been identified to date and this is most likely due to the same reasons as in the case of Diplonema LSU, namely the extreme divergence of the corresponding mito-rRNAs ${ }^{35,37}$.

\section{Mechanisms of mitochondrial gene expression}

In all euglenozoans, mtDNA is transcribed into polycistrons, which undergo endonucleolytic cleavage and further editing or processing (or both) into translatable mRNAs (Figure 4). In kinetoplastids, the majority of mt-encoded genes exist in a cryptic form, as their corresponding transcripts have to undergo extensive posttranscriptional RNA editing of the uridine insertion/deletion type (for recent reviews, see 19,27,28). In Diplonema, only a few insertions of blocks of uridines have been documented so far $^{31,32}$. RNA editing in Trypanosoma and related flagellates is extremely complex, as the insertions and deletions of hundreds and dozens of uridines, respectively, are performed by a multitude of gRNAs and several protein complexes that interact in a highly dynamic manner 28,38 . Upon the addition of complex poly-U/A tails ${ }^{27,28}$ (Figure 4), the fully edited transcripts are translated on proteinrich and rRNA-poor ribosomes ${ }^{39}$, but the role of the additional $45 \mathrm{~S}$ ribosomal subunit of unique protein composition is still unclear ${ }^{40}$. Likely owing to their extreme hydrophobicity, only a few of the de novo synthesized $\mathrm{mt}$ proteins have been observed ${ }^{41,42}$.

The post-transcriptional processing is very different in Diplonema, where fragments of genes transcribed from individual DNA circles are trans-spliced in a highly systematic $5^{\prime}$ to $3^{\prime}$ progression ${ }^{31,33}$. The genome and mitoproteome of Diplonema may eventually shed light on this unique processing, but so far the proteins (and potentially also small RNAs) involved in it remain completely unknown. In any case, it is highly likely that the fully trans-spliced mRNAs are in organello translated (our unpublished data). Indeed, the recently described simplicity of mt mRNA processing in Euglena ${ }^{37}$ and likely other euglenids is in stunning contrast with the baroque complexity of RNA editing or trans-splicing (or both) in kinetoplastids and diplonemids (Figure 4 and Table 1).

\section{Why are mitochondrial genomes in Euglenozoa so diverse}

Soon after its discovery, RNA editing in kinetoplastids was explained as a remnant of the RNA world ${ }^{43}$, but the absence of similar mechanisms in both sister clades ${ }^{33,37}$ puts this scenario finally to rest. A more plausible explanation postulates that gene fragmentation in the euglenozoan last common ancestor was "the seed of future chaos", leading to the emergence of extremely complex post-transcriptional mechanisms, differing in each sister lineage, yet eventually correcting the scrambling on the posttranscriptional level ${ }^{44}$. In fact, it was argued that the kinetoplastid RNA editing is a prime example of "irremediable complexity", a rampant mechanism that does not provide any selective advantage yet fixes the problem ${ }^{38,45}$. The recent finding of a standard $\mathrm{mt}$ genome in Euglena ${ }^{37}$ implies that the irreversible scrambling 
RNA editing of cytochrome c oxidase subunit 1 (coxI) transcript in ...

$\begin{array}{ll} & \text { mRNA } \\ \text { Euglena } & \text { polyadenylation } \\ \text { AUGCAGUCUGA..... } & \text { trans - splicing site } \\ & \text { site for uridine insertion } \\ \text { and trans-splicing }\end{array}$

AUGuuUAG **GACUuAGAA* $\quad$...ACGCAGUCUAA AAAAA...

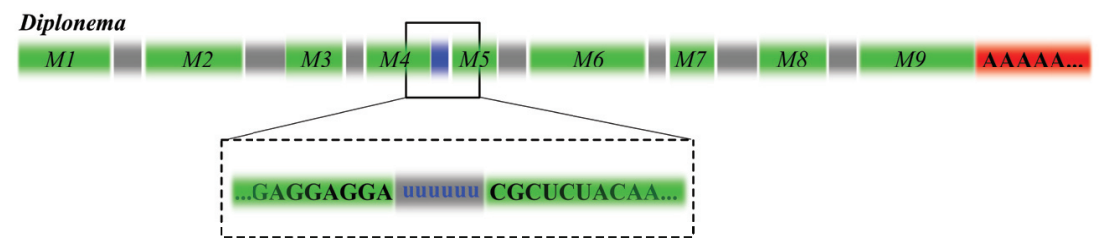

Figure 4. The comparison of RNA processing of the cox1 transcript in representative euglenozoans. In contrast to Trypanoplasma borreli and Diplonema papillatum, the cytochrome $c$ oxidase subunit 1 (cox1) transcript of Euglena gracilis (in green) does not undergo RNA editing, splicing, or polyadenylation prior to its translation. In Trypanoplasma, cox1 undergoes RNA editing in the form of numerous uridine insertions (small blue "u") and deletions (blue star), followed by polyadenylation (in red). The Diplonema cox 1 transcript is formed by trans-splicing of nine small fragments called modules M1 thru M9 (in grey), which is accompanied by the insertion of six uridines between the modules M4 and M5. Finally, the transcript is polyadenylated and translated on mitochondrial ribosomes.

Table 1. Architecture and gene content of mitochondrial genomes of representative euglenozoans and humans.

\begin{tabular}{|c|c|c|c|c|}
\hline & Trypanosoma brucei & $\begin{array}{l}\text { Diplonema } \\
\text { papillatum }\end{array}$ & Euglena gracilis & Human \\
\hline Type of mitochondrial cristae & Discoidal & Discoidal & Discoidal & Tubular \\
\hline Mode of life & Parasitic & $\begin{array}{l}\text { Phagotrophic } \\
\text { osmotrophic }\end{array}$ & $\begin{array}{l}\text { Mixotrophic } \\
\text { heterotrophic } \\
\text { autotrophic }\end{array}$ & Heterotrophic \\
\hline Habitat & $\begin{array}{l}\text { Insect gut } \\
\text { mammalian bloodstream }\end{array}$ & Marine & Freshwater & - \\
\hline Genome structure & Circular & Circular & Linear & Circular \\
\hline Genome protein-coding genes & 18 & 10 & 7 & 13 \\
\hline rRNA (SSU/LSU) & $+/+$ & $? /+$ & $+/ ?$ & $+/+$ \\
\hline tRNA & - & - & - & 22 \\
\hline Genome size & $\begin{array}{l}\text { Maxicircles: } \sim 20.0 \mathrm{~kb} \\
\text { Minicircles: } \sim 1.0 \mathrm{~kb}\end{array}$ & $\begin{array}{l}\text { Class A: } 6.0 \mathrm{~kb} \\
\text { Class B: } 7.0 \mathrm{~kb}\end{array}$ & $\sim 1.0$ to $\sim 9.0 \mathrm{~kb}$ & $16.6 \mathrm{~kb}$ \\
\hline Genome copy number & $\begin{array}{l}\text { Maxicircles: } \sim \text { dozens } \\
\text { Minicircles: } \sim 5,000\end{array}$ & $\sim 100$ & $?$ & $\sim 50$ to $1 \times 10^{5}$ \\
\hline Transcript polyadenylation & Yes & Yes & No & $\mathrm{No}^{*}$ \\
\hline Trans-splicing & No & Yes & No & No \\
\hline Uridine insertions & Yes & Yes & No & No \\
\hline Uridine deletions & Yes & No & No & No \\
\hline Introns & No & No & No & No \\
\hline
\end{tabular}

*Yes if, as in some cases, the termination codons are added post-transcriptionally by polyadenylation of the mRNAs. SSU/LSU, small subunit/large subunit. 
originally implied for the mtDNA of the euglenozoan last common ancestor ${ }^{44}$ did happen at a later stage in evolution, probably in the predecessor of diplonemids and kinetoplastids. Although despite the available sequence data, the mutual relationships among the three euglenozoan lineages remain unresolved, and we can predict, on the basis of their mt genomes and transcriptomes, that the mostly free-living photosynthetic euglenids constitute the earliest offshoot of the long euglenozoan branch.

\section{Competing interests}

The authors declare that they have no competing interests.

\section{Grant information}

This work was funded by Gordon and Betty Moore Foundation grant GBMF4983 and Czech Grant Agency 15-21974S to Julius Lukeš.

The funders had no role in study design, data collection and analysis, decision to publish, or preparation of the manuscript.

\section{Acknowledgments}

The scanning electron micrographs of Diplonema and Trypanosoma were kindly provided by Binnypreet Kaur and Eva Horáková (Biology Centre, České Budějovice), respectively.
1. F Adl SM, Simpson AG, Lane CE, et al.: The revised classification of eukaryotes. J Eukaryot Microbiol. 2012; 59(5): 429-93.

PubMed Abstract | Publisher Full Text | Free Full Text | F1000 Recommendation

2. Lukeš J, Skalický T, Týč J, et al.: Evolution of parasitism in kinetoplastid flagellates. Mol Biochem Parasitol. 2014; 195(2): 115-22.

PubMed Abstract | Publisher Full Text

3. F Hampl V, Hug L, Leigh JW, et al.: Phylogenomic analyses support the monophyly of Excavata and resolve relationships among eukaryotic "supergroups". Proc Natl Acad Sci U S A. 2009; 106(10): 3859-64. PubMed Abstract | Publisher Full Text | Free Full Text | F1000 Recommendation

4. de Vargas C, Audic S, Henry N, et al.: Ocean plankton. Eukaryotic plankton diversity in the sunlit ocean. Science. 2015; 348(6237): 1261605. PubMed Abstract | Publisher Full Text

5. Lukeš J, Flegontova O, Horák A: Diplonemids. Curr Biol. 2015; 25(16): R702-4 PubMed Abstract | Publisher Full Text

6. Tielens AG, van Hellemond JJ: Surprising variety in energy metabolism within Trypanosomatidae. Trends Parasitol. 2009; 25(10): 482-90. PubMed Abstract | Publisher Full Text

7. Zíková A, Hampl V, Paris Z, et al.: Aerobic mitochondria of parasitic protists: Diverse genomes and complex functions. Mol Biochem Parasitol. 2016; pii: S0166-6851(16)30015-9 PubMed Abstract | Publisher Full Text

8. F Marande W, Lukes J, Burger G: Unique mitochondrial genome structure in diplonemids, the sister group of kinetoplastids. Eukaryot Cell. 2005; 4(6): 1137-46.

PubMed Abstract | Publisher Full Text | Free Full Text | F1000 Recommendation

9. $\quad F$ Smith DR, Keeling PJ: Mitochondrial and plastid genome architecture: Reoccurring themes, but significant differences at the extremes. Proc Natl Acad Sci U S A. 2015; 112(33): 10177-84.

PubMed Abstract | Publisher Full Text | Free Full Text | F1000 Recommendation

10. Pawlowski J, Audic S, Adl S, et al.: CBOL protist working group: barcoding eukaryotic richness beyond the animal, plant, and fungal kingdoms. PLOS Biol. 2012; 10(11): e1001419.

PubMed Abstract | Publisher Full Text | Free Full Text

11. Gray MW: Diversity and evolution of mitochondrial RNA editing systems. IUBMB Life. 2003; 55(4-5): 227-33. PubMed Abstract | Publisher Full Text

12. Smith DR: The past, present and future of mitochondrial genomics: have we sequenced enough mtDNAs? Brief Funct Genomics. 2016; 15(1): 47-54. PubMed Abstract | Publisher Full Text

13. Flegontov $P$, Michálek $\mathrm{J}$, Janouškovec $\mathrm{J}$, et al.: Divergent mitochondrial respiratory chains in phototrophic relatives of apicomplexan parasites. $\mathrm{MO}$ Biol Evol. 2015; 32(5): 1115-31. PubMed Abstract | Publisher Full Tex

14. F Burger G, Gray MW, Forget L, et al:: Strikingly bacteria-like and gene-rich mitochondrial genomes throughout jakobid protists. Genome Biol Evol. 2013; 5(2): 418-38.

PubMed Abstract | Publisher Full Text | Free Full Text | F1000 Recommendation

15. Roy J, Faktorová D, Lukes J, et al.: Unusual mitochondrial genome structures throughout the Euglenozoa. Protist. 2007; 158(3): 385-96. PubMed Abstract | Publisher Full Text

16. Lukes J, Guilbride DL, Votýpka J, et al.: Kinetoplast DNA network: evolution of an improbable structure. Eukaryot Cell. 2002; 1(4): 495-502.

PubMed Abstract | Publisher Full Text | Free Full Text

17. F Jensen RE, Englund PT: Network news: the replication of kinetoplast DNA. Annu Rev Microbiol. 2012; 66: 473-91.

PubMed Abstract | Publisher Full Text | F1000 Recommendation

18. Povelones ML: Beyond replication: division and segregation of mitochondrial DNA in kinetoplastids. Mol Biochem Parasitol. 2014; 196(1): 53-60. PubMed Abstract | Publisher Full Text

19. Verner Z, Basu S, Benz C, et al:: Malleable mitochondrion of Trypanosoma brucei. Int Rev Cell Mol Biol. 2015; 315: 73-151.

PubMed Abstract | Publisher Full Text

20. Liu B, Liu Y, Motyka SA, et al:: Fellowship of the rings: the replication of kinetoplast DNA. Trends Parasitol. 2005; 21(8): 363-9. PubMed Abstract | Publisher Full Text

21. Borst P, Fase-Fowler F, Weijers PJ, et al.: Kinetoplast DNA from Trypanosoma vivax and T. congolense. Mol Biochem Parasitol. 1985; 15(2): 129-42. PubMed Abstract | Publisher Full Text

22. Sloof $\mathrm{P}$, de Haan $\mathrm{A}$, Eier $\mathrm{W}$, et al:: The nucleotide sequence of the variable region in Trypanosoma brucei completes the sequence analysis of the maxicircle component of mitochondrial kinetoplast DNA. Mol Biochem Parasitol. 1992; 56(2): 289-99.

PubMed Abstract | Publisher Full Text

23. Shapiro TA, Englund PT: The structure and replication of kinetoplast DNA. Annu Rev Microbiol. 1995; 49: 117-43.

PubMed Abstract | Publisher Full Text

24. Benne R, De Vries BF, Van den Burg J, et al.: The nucleotide sequence of segment of Trypanosoma brucei mitochondrial maxi-circle DNA that contains the gene for apocytochrome $b$ and some unusual unassigned reading frames. Nucleic Acids Res. 1983; 11(20): 6925-41.

PubMed Abstract | Publisher Full Text | Free Full Text

25. Simpson L, Neckelmann N, de la Cruz VF, et al:: Comparison of the maxicircle (mitochondrial) genomes of Leishmania tarentolae and Trypanosoma brucei at the level of nucleotide sequence. J Biol Chem. 1987; 262(13): 6182-96. PubMed Abstract

26. F Koslowsky D, Sun Y, Hindenach J, et al:: The insect-phase gRNA transcriptome in Trypanosoma brucei. Nucleic Acids Res. 2014; 42(3): 1873-86. PubMed Abstract | Publisher Full Text | Free Full Text | F1000 Recommendation

27. Aphasizhev R, Aphasizheva I: Mitochondrial RNA editing in trypanosomes: small RNAs in control. Biochimie. 2014; 100: 125-31. PubMed Abstract | Publisher Full Text | Free Full Text

28. Read LK, Lukeš J, Hashimi H: Trypanosome RNA editing: the complexity of getting $\mathbf{U}$ in and taking $\mathrm{U}$ out. Wiley Interdiscip Rev RNA. 2016; 7(1): 33-51. PubMed Abstract | Publisher Full Text

29. Alfonzo JD, Blanc V, Estévez AM, et al.: $\mathbf{C}$ to $\mathbf{U}$ editing of the anticodon of imported mitochondrial tRNA ${ }^{\text {Trp }}$ allows decoding of the UGA stop codon in Leishmania tarentolae. EMBO J. 1999; 18(24): 7056-62. PubMed Abstract | Publisher Full Text | Free Full Text

30. Alfonzo JD, Söll D: Mitochondrial tRNA import--the challenge to understand has just begun. Biol Chem. 2009; 390(8): 717-22. PubMed Abstract | Publisher Full Text

31. Vlcek C, Marande W, Teijeiro S, et al.: Systematically fragmented genes in a multipartite mitochondrial genome. Nucleic Acids Res. 2011; 39(3): 979-88. PubMed Abstract | Publisher Full Text | Free Full Text 
32. $\mathrm{F}$ Kiethega GN, Yan Y, Turcotte M, et al.: RNA-level unscrambling of fragmented genes in Diplonema mitochondria. RNA Biol. 2013; 10(2): 301-13. PubMed Abstract | Publisher Full Text | Free Full Text | F1000 Recommendation

33. Marande W, Burger G: Mitochondrial DNA as a genomic jigsaw puzzle. Science. 2007; 318(5849): 415.

PubMed Abstract | Publisher Full Text

34. F Valach M, Burger G, Gray MW, et al.: Widespread occurrence of organelle genome-encoded $5 \mathrm{~S}$ rRNAs including permuted molecules. Nucleic Acids Res. 2014; 42(22): 13764-77.

PubMed Abstract | Publisher Full Text | Free Full Text | F1000 Recommendation

35. F Spencer DF, Gray MW: Ribosomal RNA genes in Euglena gracilis mitochondrial DNA: fragmented genes in a seemingly fragmented genome. Mol Genet Genomics. 2011; 285(1): 19-31.

PubMed Abstract | Publisher Full Text | F1000 Recommendation

36. Tessier $\mathrm{LH}$, van der Speck $\mathrm{H}$, Gualberto JM, et al.: The cox1 gene from Euglena gracilis: a protist mitochondrial gene without introns and genetic code modifications. Curr Genet. 1997; 31(3): 208-13.

PubMed Abstract | Publisher Full Text

37. Dobáková E, Flegontov $P$, Skalický $T$, et al.: Unexpectedly Streamlined Mitochondrial Genome of the Euglenozoan Euglena gracilis. Genome Biol Evol. 2015; 7(12): 3358-67.

PubMed Abstract | Publisher Full Text | Free Full Text

38. Lukeš J, Archibald JM, Keeling PJ, et al:: How a neutral evolutionary ratchet can build cellular complexity. IUBMB Life. 2011; 63(7): 528-37.

PubMed Abstract | Publisher Full Text
39. F Zíková A, Panigrahi AK, Dalley RA, et al:: Trypanosoma brucei mitochondrial ribosomes: affinity purification and component identification by mass spectrometry. Mol Cell Proteomics. 2008; 7(7): 1286-96.

PubMed Abstract | Publisher Full Text | Free Full Text | F1000 Recommendation

40. Ridlon L, Škodová I, Pan S, et al.: The importance of the $45 \mathrm{~S}$ ribosomal small subunit-related complex for mitochondrial translation in Trypanosoma brucei. J Biol Chem. 2013; 288(46): 32963-78. PubMed Abstract | Publisher Full Text | Free Full Text

41. F Horvath A, Kingan TG, Maslov DA: Detection of the mitochondrially encoded cytochrome $\mathrm{c}$ oxidase subunit I in the trypanosomatid protozoan Leishmania tarentolae. Evidence for translation of unedited mRNA in the kinetoplast. J Biol Chem. 2000; 275(22): 17160-5.

PubMed Abstract | Publisher Full Text | F1000 Recommendation

42. F Škodová-Sveráková I, Horváth A, Maslov DA: Identification of the mitochondrially encoded subunit 6 of $F_{1} F_{0}$ ATPase in Trypanosoma brucei. Mol Biochem Parasitol. 2015; 201(2): 135-8.

PubMed Abstract | Publisher Full Text | Free Full Text | F1000 Recommendation

43. Cech TR: RNA editing: world's smallest introns? Cell. 1991; 64(4): 667-9. PubMed Abstract | Publisher Full Text

44. Flegontov P, Gray MW, Burger G, et al:: Gene fragmentation: a key to mitochondrial genome evolution in Euglenozoa? Curr Genet. 2011; 57(4): 225-32.

PubMed Abstract | Publisher Full Text

45. Gray MW, Lukes J, Archibald JM, et al.: Cell biology. Irremediable complexity? Science. 2010; 330(6006): 920-1.

PubMed Abstract | Publisher Full Text 


\section{Open Peer Review}

\section{Current Peer Review Status:}

\section{Editorial Note on the Review Process}

Faculty Reviews are review articles written by the prestigious Members of Faculty Opinions. The articles are commissioned and peer reviewed before publication to ensure that the final, published version is comprehensive and accessible. The reviewers who approved the final version are listed with their names and affiliations.

\section{The reviewers who approved this article are:}

\section{Version 1}

\section{Daniel Sloan}

Colorado State University, Fort Collins, CO, USA

Competing Interests: No competing interests were disclosed.

\section{Thomas Becker}

University of Freiburg, Freiburg, Germany

Competing Interests: No competing interests were disclosed.

The benefits of publishing with F1000Research:

- Your article is published within days, with no editorial bias

- You can publish traditional articles, null/negative results, case reports, data notes and more

- The peer review process is transparent and collaborative

- Your article is indexed in PubMed after passing peer review

- Dedicated customer support at every stage

For pre-submission enquiries, contact research@f1000.com 